\title{
Molecular detection and genotyping of bovine viral diarrhea virus in Western China
}

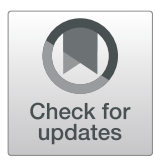

Lingling Chang ${ }^{\dagger}$, Yanping $\mathrm{Qi}^{\dagger}$, Dan Liu, Qian Du, Xiaomin Zhao* and Dewen Tong ${ }^{*}$

\begin{abstract}
Background: Bovine viral diarrhea virus (BVDV) is an important global viral pathogen of cattle and other ruminants. To survey the infection rate and genetic diversity of BVDV in western China, a total of 1234 serum samples from 17 herds of dairy cattle, beef cattle and yak in 4 provinces were collected in 2019.

Results: All the 1234 serum samples were screened individually for BVDV by RT-PCR. Our results demonstrated that the average positive rate of BVDV was 7.2\% (89/1234) in animals and 82.4\% (14/17) in herds. Thirteen BVDV strains were isolated from RT-PCR positive clinical samples and they were all NCP biotype. BVDV-1a and 1c subgenotypes were identified from 22 selected virus isolates in 14 BVDV-positive herds. These results confirmed that BVDV-1a and BVDV-1c were circulating in western China, similar to the BVDV epidemics in cattle in other regions of China.
\end{abstract}

Conclusions: This study provides data for monitoring and vaccination strategies of BVDV in western China.

Keywords: BVDV, RT-PCR, Genotype, Bovine, Western China

\section{Background}

Bovine viral diarrhea virus (BVDV) is an important pathogen of cattle worldwide and causes significant economic losses. BVDV has been detected in not only in cattle, but also in diverse domestic $[1,2]$ and wildlife animal species [3-5].

BVDV is a member of the Pestivirus genus within the family Flaviviridae. There are two common BVDV genetic species, BVDV-1 and BVDV-2. However, a newly recognized pestivirus species, "HoBi-like" or "atypical pestiviruses" has been considered as the third genetic species of BVDV [6,7], and entitled as BVDV-3.The BVDV genome consists of a single-stranded, plus-sense RNA approximately $12.3 \mathrm{~kb}$ in length, which is flanked by $5^{\prime}$ and 3 'untranslated regions ( $5^{\prime}$ UTR, 3'UTR) and encodes 11-12 structural and non-structural proteins (Npro, C, Erns, E1, E2, P7, NS2/3, NS4A, NS4B, NS5A, NS4B). BVDV can be divided into two biotypes,

\footnotetext{
* Correspondence: xiaominz@nwafu.edu.cn; dwtong@nwsuaf.edu.cn ${ }^{+}$Lingling Chang and Yanping Qi contributed equally to this work. College of Veterinary Medicine, Northwest A\&F University, Yangling, Shaanxi, China
}

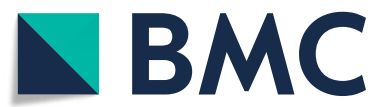

cytopathic (CP) and noncytopathic (NCP), based on its ability of the production of the visible effects on cell culture [8]. The 5'UTR region has primarily been used for subgenotype identification as well as $\mathrm{N}^{\text {pro }}$ and $\mathrm{E} 2$ regions $[7,9-15]$. On the basis of the 5'UTR, various subgenotypes of BVDV isolates have been identified. To date, 21 subgenotypes within the BVDV1 $(1 \mathrm{a}-1 \mathrm{u})$ and 3 subgenotypes of BVDV2 have been reported worldwide [10, 14, 16], which predominate in different countries. In China, nine subgenotypes have been identified in cattle, including $1 \mathrm{a}, 1 \mathrm{~b}, 1 \mathrm{c}, 1 \mathrm{~d}, 1 \mathrm{~m}, 1 \mathrm{o}, 1 \mathrm{p}, 1 \mathrm{q}$, and $1 \mathrm{u}[17,18]$.

Previous studies showed that a high proportion of BVDV-positive cattle came from western China [19, 20], because these areas are historically the main regions with cattle production. However, studies regarding the genetic diversity of BVDV in western China remain rare $[4,21,22]$. Thus, this study detected and genotyped BVDV from bovines in this region. Such studies are important to understand the diversity of viral strains present in one region and this, in turn, can inform control programs, drive vaccine development and determine likely infection sources.

(c) The Author(s). 2021 Open Access This article is licensed under a Creative Commons Attribution 4.0 International License, which permits use, sharing, adaptation, distribution and reproduction in any medium or format, as long as you give appropriate credit to the original author(s) and the source, provide a link to the Creative Commons licence, and indicate if changes were made. The images or other third party material in this article are included in the article's Creative Commons licence, unless indicated otherwise in a credit line to the material. If material is not included in the article's Creative Commons licence and your intended use is not permitted by statutory regulation or exceeds the permitted use, you will need to obtain permission directly from the copyright holder. To view a copy of this licence, visit http://creativecommons.org/licenses/by/4.0/ The Creative Commons Public Domain Dedication waiver (http://creativecommons.org/publicdomain/zero/1.0/) applies to the data made available in this article, unless otherwise stated in a credit line to the data. 


\section{Results}

\section{Detection of BVDV in clinical serum samples}

A total of 1234 serum samples were tested for BVDV by 5'UTR RT-PCR. As shown in Table 1, the average positive rate of BVDV in animals was 7.2\% (89/1234). At the herd level, a herd was considered positive if one serum sample was positive in RT-PCR testing. Thus, $82.4 \%$ (14/ 17) of herds were positive and they were located in Shaanxi, Ningxia, Xinjiang, and Tibet. No BVDV infection was found in 3 herds from Shaanxi and Ningxia Provinces. The average positive rate of BVDV in Shaanxi, Ningxia, Xinjiang, and Tibet was $4.57 \%(44 /$ 963), $30 \%$ (18/60), 37.5\% (6/16) and $10.77 \%(21 / 195)$, respectively.

\section{Virus isolation}

BVDV strains were isolated from RT-PCR positive clinical samples and they were identified by immunofluorescence, RT-PCR and sequence analysis, and transmission electron microscopy.

Initially all of the 89 positive samples were subjected to virus isolation, but only 13 BVDV strains were successfully isolated (Fig. 1a-c; S1 Figure). The isolated BVDV strains were named as SX-01XN19, SX-02XN19, NX-05XN19, NX-69209, NX-03XN19, NX-59181, NX59211, NX-04XN19, NX-10XN19, XJ-06XN19, XJ07XN19, XJ-08XN19 and XZ-09XN19, respectively. All the 13 strains caused no obvious cell lesions, hence, they were identified as NCP biotype (Fig. 1a). Transmission electron microscopy examination showed typical viral particles in the cytoplasm of MDBK cell, which were measured approximately $60 \mathrm{~nm}$ in diameter and occurred as clusters inside vesicles (Fig. 1b). The information of these BVDV strains including source, biotype, and genotype was presented in Table 2 .

\section{Sequencing and phylogenetic analysis}

To investigate the extent of genetic diversity of BVDV in western China, the subgenotypes of the BVDV isolates were determined by 5 'UTR sequencing and phylogenetic analysis.

As shown in Tables 2, 22 virus isolates, including 13 isolated strains and 9 positive serum samples, were randomly selected from 14 BVDV positive herds and used for phylogenetic analysis. BLAST search revealed that all sequences belonged to BVDV-1. As shown in Fig. 2, phylogenetic analysis revealed that these isolates clustered into either BVDV-1a $(n=14)$ or BVDV-1c $(n=8)$ subgenotypes. The BVDV-1a subgenotypes were located in Shaanxi $(n=9)$, Ningxia $(n=1)$, Xinjiang $(n=3)$ and Tibet $(n=1)$, and the BVDV-1c located in Shaanxi $(n=1)$, Ningxia $(n=6)$ and Tibet $(n=1)$.

Table 1 Samples collected and RT-PCR detection of BVDV

\begin{tabular}{|c|c|c|c|c|c|c|c|c|c|}
\hline $\begin{array}{l}\text { Herd } \\
\text { No. }\end{array}$ & Provinces & Species & Date & $\begin{array}{l}\text { Clinical } \\
\text { symptoms }\end{array}$ & $\begin{array}{l}\text { No. sample } \\
\text { collected }\end{array}$ & $\begin{array}{l}\text { No. positive } \\
\text { sample }\end{array}$ & $\begin{array}{l}\text { Positive rate in } \\
\text { sample }\end{array}$ & $\begin{array}{l}\text { Status in } \\
\text { herd }\end{array}$ & $\begin{array}{l}\text { Positive rate in } \\
\text { province }\end{array}$ \\
\hline 1 & Shaanxi & Dairy & 2019.3 & Diarrhea & 45 & 0 & $0(0 / 45)$ & - & $4.57 \%(44 / 963)$ \\
\hline 2 & & Beef & 2019.4 & Diarrhea & 47 & 0 & $0(0 / 47)$ & - & \\
\hline 3 & & Diary & 2019.5 & Healthy & 137 & 5 & $3.65 \%(5 / 137)$ & + & \\
\hline 4 & & Diary & 2019.5 & Diarrhea & 29 & 2 & $6.90 \%(2 / 29)$ & + & \\
\hline 5 & & Beef & 2019.5 & Healthy & 211 & 10 & $4.74 \%(10 / 211)$ & + & \\
\hline 6 & & Diary & 2019.5 & Diarrhea & 43 & 8 & $18.60 \%(8 / 43)$ & + & \\
\hline 7 & & Beef & 2019.6 & Healthy & 116 & 9 & $7.76 \%(9 / 116)$ & + & \\
\hline 8 & & Beef & 2019.6 & Diarrhea & 25 & 1 & $4 \%(1 / 25)$ & + & \\
\hline 9 & & Diary & 2019.12 & Diarrhea & 280 & 7 & $2.50 \%(7 / 280)$ & + & \\
\hline 10 & & Diary & 2019.12 & Diarrhea & 30 & 2 & $6.67 \%(2 / 30)$ & + & \\
\hline 11 & Ningxia & Diary & 2019.4 & Diarrhea & 13 & 2 & $15.38 \%(2 / 13)$ & + & $30 \%(18 / 60)$ \\
\hline 12 & & Diary & 2019.4 & Diarrhea & 10 & 6 & $60 \%(6 / 10)$ & + & \\
\hline 13 & & Beef & 2019.4 & Diarrhea & 15 & 10 & $66.67 \%(10 / 15)$ & + & \\
\hline 14 & & Diary & 2019.9 & Diarrhea & 22 & 0 & $0(0 / 22)$ & - & \\
\hline 15 & Xinjiang & Diary & 2019.8 & Diarrhea & 16 & 6 & $37.50 \%(6 / 16)$ & + & $37.5 \%(6 / 16)$ \\
\hline 16 & Tibet & Yak & 2019.7 & Diarrhea & 98 & 15 & $15.31 \%(15 / 98)$ & + & $10.77 \%(21 / 195)$ \\
\hline \multirow[t]{2}{*}{17} & & Yak & 2019.9 & Diarrhea & 97 & 6 & $6.19 \%(6 / 97)$ & + & \\
\hline & & & & & 1234 & 89 & $7.2 \%(89 / 1234)$ & $\begin{array}{l}{ }^{a} 82.4 \%(14 / \\
17)\end{array}$ & \\
\hline
\end{tabular}




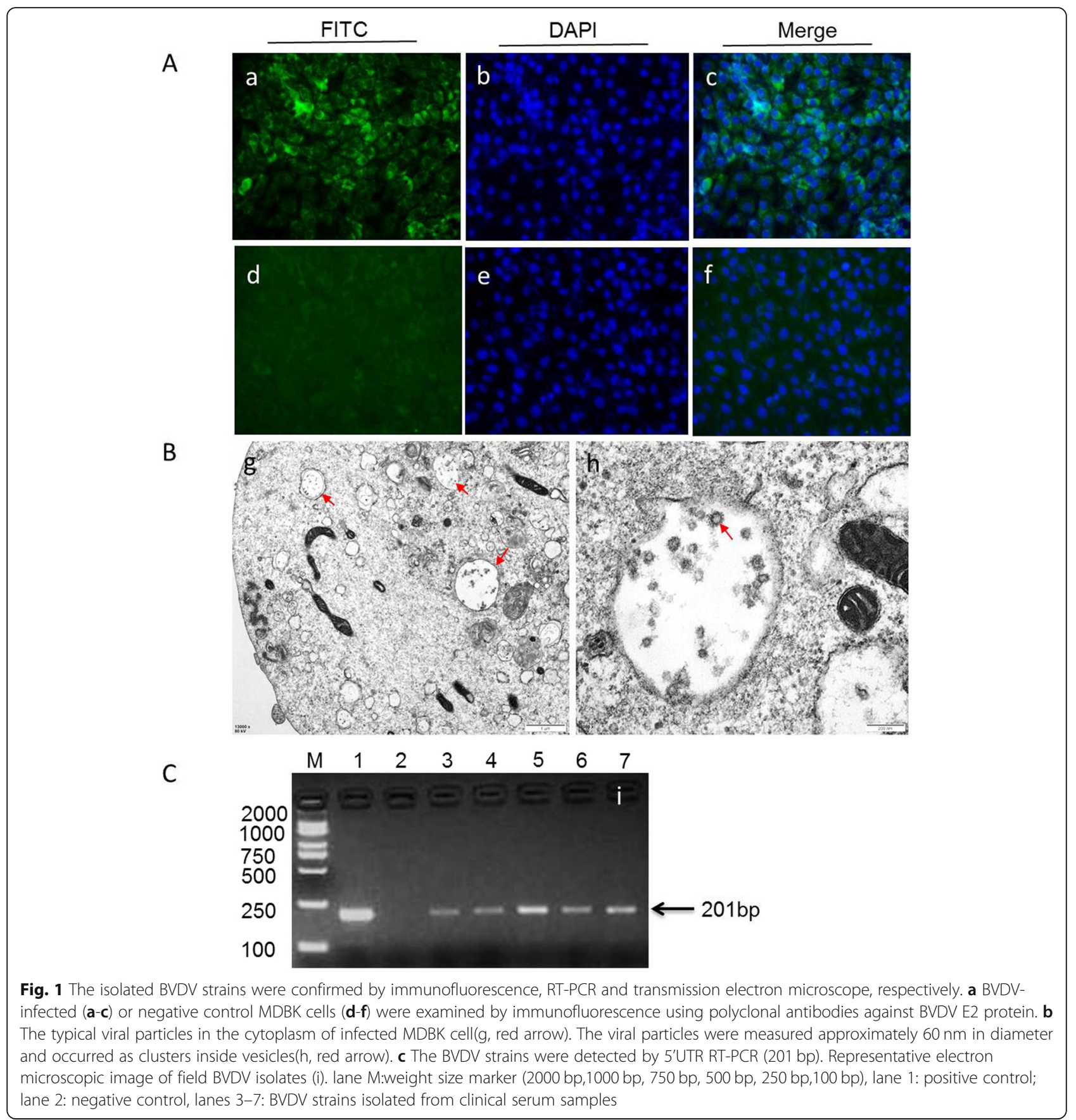

\section{Discussion}

In this study, we investigated the prevalence and genetic diversity of BVDV among bovines in western China. The BVDV positive rate varies greatly among bovine herds due to the variety of detection tests, sampling methods, species, and locations. Hence, it is difficult to determine the exact extent of the BVDV prevalence in China. As previously reported, RT-PCR analysis of BVDV RNA is more sensitive than other $\mathrm{Ag}$ detection methods and has been widely used for BVDV detection. Primer is pivotal for the accuracy and sensitive of RT-PCR detection. In this study, the primers BP189-389 for 5'UTR region was used, which had a broad range of bovine pestivirus detection including BVDV-1, BVDV-2 and BVDV-3 [23].

Our results demonstrated that the average positive rate of BVDV in animals was $7.2 \%$ (89/1234). Previous reports showed that the RNA prevalence of BVDV was 22.64\% among bovine in China [17]. A systematic review and meta-analysis showed that the RNA prevalence of BVDV was $27.1 \%$ in dairy cattle in China [19]. In our 
Table 2 List of field virus isolates used in the study

\begin{tabular}{|c|c|c|c|c|c|c|}
\hline Virus isolate & Herd & Material & Origin & Genotype & Biotype & GenBank accession no. \\
\hline SX-02XN19 & 3 & Cell culture & Shaanxi & $1 \mathrm{a}$ & ncp & MT316318 \\
\hline$S X-2$ & 3 & Serum & Shaanxi & $1 a$ & $a_{-}$ & MW142339 \\
\hline$S X-1-2$ & 4 & Serum & Shaanxi & $1 a$ & - & MW142341 \\
\hline SX-01XN19 & 5 & Cell culture & Shaanxi & $1 \mathrm{c}$ & nсp & MT316327 \\
\hline $5 X-3$ & 6 & Serum & Shaanxi & $1 \mathrm{a}$ & - & MW142340 \\
\hline SX-219 & 7 & Serum & Shaanxi & $1 a$ & - & MW142338 \\
\hline$S X-1-1$ & 8 & Serum & Shaanxi & $1 a$ & - & MW142343 \\
\hline$S X-3-46$ & 9 & Serum & Shaanxi & $1 a$ & - & MW142342 \\
\hline$S X-3-2$ & 9 & Serum & Shaanxi & $1 \mathrm{a}$ & - & MW142344 \\
\hline$S X-3-53$ & 10 & Serum & Shaanxi & $1 a$ & - & MW142345 \\
\hline NX-69209 & 11 & Cell culture & Ningxia & $1 a$ & ncp & MW142337 \\
\hline NX-03XN19 & 12 & Cell culture & Ningxia & $1 \mathrm{c}$ & ncp & MT316319 \\
\hline NX-59181 & 12 & Cell culture & Ningxia & $1 \mathrm{c}$ & ncp & MW142336 \\
\hline NX-59211 & 12 & Cell culture & Ningxia & $1 \mathrm{c}$ & ncp & MW142335 \\
\hline NX-04XN19 & 12 & Cell culture & Ningxia & $1 \mathrm{c}$ & $\mathrm{ncp}$ & MT316320 \\
\hline NX-10XN19 & 12 & Cell culture & Ningxia & $1 \mathrm{c}$ & ncp & МT316325 \\
\hline NX-05XN19 & 13 & Cell culture & Ningxia & $1 a$ & ncp & MT316321 \\
\hline XJ-06XN19 & 15 & Cell culture & Xinjiang & $1 a$ & ncp & MT316322 \\
\hline XJ-07XN19 & 15 & Cell culture & Xinjiang & $1 a$ & ncp & MT316323 \\
\hline XJ-08XN19 & 15 & Cell culture & Xinjiang & $1 a$ & $\mathrm{ncp}$ & MT316324 \\
\hline XZ-N24 & 16 & Serum & Tibet & $1 a$ & - & MW142346 \\
\hline XZ-09XN19 & 17 & Cell culture & Tibet & $\begin{array}{l}1 \mathrm{C} \\
\mathrm{C}\end{array}$ & $\mathrm{ncp}$ & MT316328 \\
\hline
\end{tabular}

${ }^{a}$ The sample was not successfully isolated from cell culture

study, there were limitations in the samplings and detection methods. Most of the clinical samples were sent to our laboratory by local farmers without providing detail information on the farms such as size and position. In addition, the sampling site did not completely cover the entire regions in western China. Considering the experimental expenses, the serology test was not performed in this study. Hence, the average RT-PCR positive rate of $7.2 \%$ in animals may not reflect the accurate prevalence of BVDV among bovines in western China. Notably, however, at herd level, we found $82.4 \%(14 / 17)$ of herds were positive for BVDV. Recently, a high prevalence of $57.78 \%$ of herds was reported to be positive for BVDV in northwestern China [1]. Our results suggested that a high proportion of herds are at risk of BVDV infection in western China.

Virus isolation is the standard method of detection of BVDV-infected cattle. The BVDV infected animals can secrete large amounts of BVDV in their serum, especially persistent infection (PI) animals. Previous studies demonstrated that BVDV remained viable in serum under normal conditions of sample submission to a diagnostic laboratory. Hence, the serum is a valid sample for the isolation of BVDV. In this study, 13 noncytopathic (NCP) strains were successfully isolated from clinical serum samples. NCP biotype is commonly found in nature. Our results further confirmed those of other workers.

BVDV is an RNA virus with high mutation rate [24]. Study investigating the frequency and number of subgenotypes of BVDV is helpful to understand the evolution of the virus and the source of infection. This information also has important implications for the design and construction of effective vaccination strategies to control BVDV [25, 26]. In this study, two subgenotypes of BVDV1a and BVDV1c were identified among 22 selected virus isolates from 14 herds. These results were in agreement with recent epidemiologic studies of BVDV in cattles in China [20, 27]. BVDV2 and BVDV3 were not detected in this study.

Although the predominant subgenotype worldwide is BVDV-1b, BVDV-1a and $-1 \mathrm{c}$ are the second and third most frequently-reported genotypes in the world, respectively [14].BVDV-1a is predominant in South Africa and is widely circulating in the United States, Korea and Japan [28], while BVDV-1c has been reported as a 


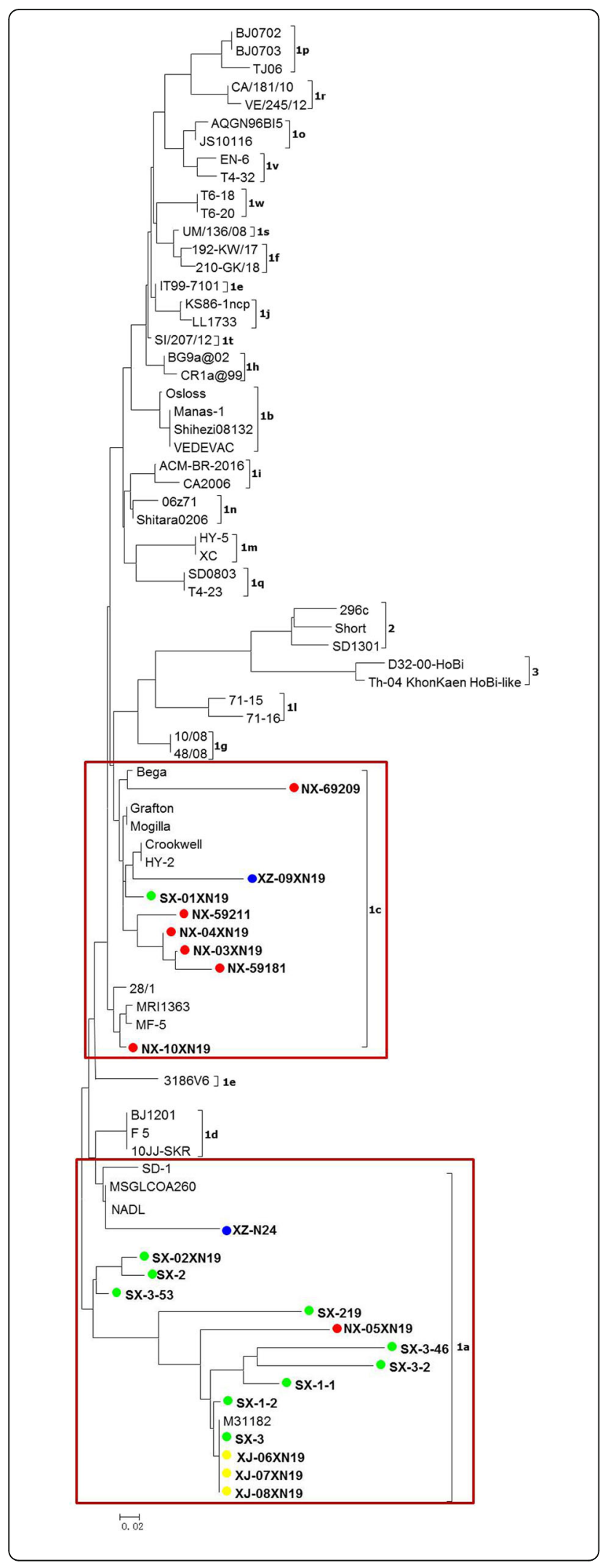

Fig. 2 Phylogenetic analysis based on 5'UTR sequence. A phylogenetic tree of the $5^{\prime} U T R$ was created using the $5^{\prime} U T R$ sequences of 22 selected BVDV isolates and 57 reference isolates retrieved from the GenBank database. $\bullet$ BVDV isolates identified in provinces of Shaanxi (green dot), Ningxia (red dot), Xinjiang (yellow dot) and Tibet (blue dot) in this study.14 isolates were clustered in BVDV-1a (frame) and 8 isolates clustered in BVDV-1c (frame)

predominant genotype in Australia [22, 28]. In China, BVDV-1a and -1c have been commonly detected in different regions of China. Recently, BVDV-1c (7/9) and BVDV-1a (1/9) strains were detected from 36 herds of dairy cattle in 5 provinces in eastern China [29]. A recent analysis of 119 BVDV sequences obtained from 92 dairy farms showed that subgenotypes of BVDV-1a $(n=$ 37, 31.09\%), BVDV-1c $(n=34,28.57 \%)$ and BVDV-1 $\mathrm{m}$ $(n=25,21.01 \%)$ were predominant in 19 provinces of China in 2017 [20].

In western China, scattered studies on the genetic diversity of BVDV among cattle and other ruminants have been reported. Subgenotypes BVDV-1b and BVDV-1c have been identified in cattle from Xinjiang Autonomous Region [22]. BVDV-1b and BVDV-1d were found predominant subgenotypes in dairy farms in Ningxia Autonomous Region [21]. Six subgenotypes of BVDV-1a, BVDV-1b, BVDV-1c, BVDV-1 m, BVDV-1o, BVDV-1p and BVDV-1q have been identified in Bactrian camels from regions of Xinjiang, Gansu and Qinghai [4]. Here, BVDV-1a was respectively detected in Shaanxi, Ningxia, Tibet and Xinjiang, and BVDV-1c was detected in Shaanxi, Ningxia, and Tibet. Taken together, our results confirmed the presence of $1 \mathrm{a}$ and $1 \mathrm{c}$ subgenotypes in western China. The genetic diversity of virus isolates hamper prevention and control of BVDV. A vaccine effective in one region may fail to protect against virus infection caused by different virus strains in another region [30]. Our findings provide important information for further characterization of the variability and geographical distribution of BVDV in China.

\section{Conclusions}

Our results demonstrated that the average positive rate of BVDV was 7.2\% (89/1234) in animals and 82.4\% (14/ 17) in herds. Thirteen BVDV strains were successfully isolated from RT-PCR positive clinical samples and they were all NCP biotype. BVDV-1a and 1c subgenotypes were identified from 22 selected isolates from 14 herds. These results confirmed that BVDV-1a and BVDV-1c were circulating in western China, similar to the BVDV epidemics in cattle in other regions of China. This study provides data for monitoring and vaccination strategies of BVDV in western China. 


\section{Methods}

\section{Clinical sample collection}

A total of 1234 serum samples from 17 herds covering 4 provinces in western China (Shaanxi, Ningxia, Xinjiang, and Tibet) were collected in 2019. Most samples were collected from herds in which the animals showed diarrhea. Some samples were submitted from clinical healthy animals for conventional detection. The sample information is summarized in Table 1.These herds were not vaccinated against BVDV. The samples were stored at $80{ }^{\circ} \mathrm{C}$ for RT-PCR and virus isolation.

\section{RT-PCR}

The clinical serum samples or cell culture were examined for the presence of BVDV by RT-PCR. Briefly, total RNA was extracted from serum or cell culture using TRIzol Reagent (Gibco). cDNA was synthesized from 1000 ng of total RNA using RNA reverse transcription kit (invitrogen USA).

The synthesized cDNA were submitted sequentially to PCR assay to amplify a 201-bp fragment of the BVDV 5'-UTR region, using referenced primers BP189-389 [21] (Forward: 5'-AGTCGTCAATGGTTCGAC-3'; Reverse: 5'-TCCATGTGCCATGTACA-3'). All PCR reaction were performed in $15 \mu \mathrm{L}$ volume containing $7.5 \mu \mathrm{L}$ of $2 \times$ PCR Master Mix (Qiagen), $2 \mu \mathrm{L}$ of cDNA, $4.5 \mu \mathrm{L}$ $\mathrm{ddH}_{2} \mathrm{O}$, and $10 \mu \mathrm{M}$ each of the primers. The reaction was carried out at $94^{\circ} \mathrm{C}$ for $4 \mathrm{~min}$, followed by 35 cycles of $94{ }^{\circ} \mathrm{C}$ for $30 \mathrm{~s}, 47^{\circ} \mathrm{C}$ for $30 \mathrm{~s}$, and $72{ }^{\circ} \mathrm{C}$ for $30 \mathrm{~s}$, with a final elongation step of $72^{\circ} \mathrm{C}$ for $7 \mathrm{~min}$. The PCR products were checked by electrophoresis on $1 \%$ agarose gel.

\section{Virus isolation}

To investigate the biotype of BVDV circulating in herds, BVDV strains were isolated from RT-PCR positive clinical samples using standard virus isolation techniques. Briefly, serum samples were placed on Madin-Darby bovine kidney (MDBK) cells for $1 \mathrm{~h}$ at $37^{\circ} \mathrm{C}$ in a $5 \% \mathrm{CO} 2$ atmosphere. The cells were washed twice with PBS and then DMEM with $2 \%$ fetal bovine serum (BVDV and BVDV antibody-free) was added and incubated for 4-5 days. Then the cultures were frozen and thawed three times and the clarified supernatant was passaged five times in MDBK cells. In the absence of cytopathic effect, the cells were fixed and stained by immunofluorescence as previously described [12]. The supernatants of the infected cells were further tested by RT-PCR described as above for the presence of BVDV nucleic acid.

\section{Transmission electron microscope}

The MDBK cell culture infected by RT-PCR positive samples were examined for the presence of BVDV particles by transmission electron microscopy (TEM). Cells were fixed with $2.5 \%$ glutaraldehyde in sodium cacodylate buffer $(0.2 \mathrm{M}, \mathrm{pH} 7.2)$, post-fixed with $1 \%$ buffered osmium tetroxide, dehydrated in acetone, and embedded in epoxy resin. The resin blocks were then cut into $60 \mathrm{~nm}$ thick ultrathin sections, stained with uranyl acetate and lead citrate, and observed in a TEM (TECNAI G2 SPIRIT BIO).

\section{Sequencing and phylogenetic analysis}

The RT-PCR amplified fragments obtained from serum samples or cell culture were directly sequenced by Shanghai Sangon Biological Engineering Technology \& Services Co., Ltd. (Shanghai, China). Multiple sequence alignment was performed using the ClustalW program in BioEdit software. Phylogenetic analysis of the 5'UTR region was performed with the neighbor-joining method in MEGA 7.0 software. In the phylogenetic tree, the evolutionary distances were computed using the Tamura 3parameter model with 1000 bootstrap replicates.

A total of 57 reference sequences of known BVDV-1, BVDV-2 and BVDV-3 isolates were obtained from the NCBI GenBank database (S2 Table). The 22 5'UTR sequences obtained in this study were deposited in GenBank (accession numbers MT316318-MT316325; MT316327-MT316328; MW142335-MW142346), see Table 2.

\section{Supplementary Information}

The online version contains supplementary material available at https://doi. org/10.1186/s12917-021-02747-7.

\section{Additional file 1.}

Additional file 2.

\section{Abbreviations}

BVDV: Bovine viral diarrhea virus; ORF: Large open reading frame; RTPCR: Reverse transcription polymerase chain reaction; PCR: Polymerase chain reaction; MDBK: Madin-darby bovine kidney cells; cDNA: Complementary DNA; CP: Cytopathogenic; NCP: Non-cytopathogenic

\section{Acknowledgments}

Not applicable.

\section{Authors' contributions}

LLC, XMZ and DWT conceived and designed the experiments. YPQ performed the experiments. LLC wrote the manuscript and analyzed the data. DL contributed to the experiments work. QD contributed to the useful discussion. DWT finalized the manuscript. All authors read and approved the manuscript.

\section{Funding}

This study has been supported by the National Nature Science Foundation of China (Grant No. 31972645). The funder had no role in study design, data collection and analysis, interpretation of data or writing of the manuscript.

Availability of data and materials

All the data supporting the results in the current study is contained within the manuscript. Sequences from this study have been deposited in NCBI GenBank under accession numbers as followed: 13 5'UTR sequences from BVDV strains isolated from MDBK cell culture with accession no. MT316318MT316325, MT316327-MT316328, MW142335-MW142337; 9 5'UTR sequences from clinical serum samples with accession no. MW142338-MW142346. 


\section{Ethics approval and consent to participate}

Serum samples used in this study had obtained based on informed consent from farm owners. Collection of serum samples from bovines was approved by the Institutional Animal Care and Use Committee (IACUC) of Northwest A\&F University (permit numbers 20161112 and 20170516).

\section{Consent for publication}

Not applicable.

\section{Competing interests}

All authors declared no competing interests.

Received: 20 July 2020 Accepted: 6 January 2021

Published online: 02 February 2021

\section{References}

1. Deng Y, Sun CQ, Cao SJ, Lin T, Yuan SS, Zhang HB, Zhai SL, Huang L, Shan $T L$, Zheng H, Wen XT, Tong GZ. High prevalence of bovine viral diarrhea virus 1 in Chinese swine herds. Vet Microbiol. 2012;159(3-4):490-3.

2. Krametter-Froetscher R, Duenser M, Preyler B, Theiner A, Benetka V, Moestl K, Baumgartner W. Pestivirus infection in sheep and goats in West Austria. Vet J. 2010:186(3):342-6.

3. Vilcek S, Nettleton PF. Pestiviruses in wild animals. Vet Microbiol. 2006 116(1-3):1-12

4. Gao S, Luo J, Du J, Lang Y, Cong G, Shao J, Lin T, Zhao F, Belak S, Liu L, Chang $\mathrm{H}$, Yin $\mathrm{H}$. Serological and molecular evidence for natural infection of Bactrian camels with multiple subgenotypes of bovine viral diarrhea virus in Western China. Vet Microbiol. 2013;163(1-2):172-6.

5. Gao Y, Wang S, Du R, Wang Q, Sun C, Wang N, Zhang P, Zhang L. Isolation and identification of a bovine viral diarrhea virus from sika deer in China. Virol J. 2011:8:83.

6. Bauermann FV, Ridpath JF. HoBi-like viruses--the typical 'atypical bovine pestivirus'. Anim Health Res Rev. 2015;16(1):64-9.

7. Gomez-Romero N, Basurto-Alcantara FJ, Verdugo-Rodriguez A, Bauermann FV, Ridpath JF. Genetic diversity of bovine viral diarrhea virus in cattle from Mexico. J Vet Diagn Investig. 2017;29(3):362-5.

8. Ammari M, McCarthy FM, Nanduri B, Pinchuk LM. Analysis of Bovine Vira Diarrhea Viruses-infected monocytes: identification of cytopathic and noncytopathic biotype differences. BMC Bioinformatics. 2010;11(Suppl 6):S9.

9. Abe Y, Tamura T, Torii S, Wakamori S, Nagai M, Mitsuhashi K, Mine J, Fujimoto Y, Nagashima N, Yoshino F, Sugita Y, Nomura T, Okamatsu M, Kida $H$, Sakoda Y. Genetic and antigenic characterization of bovine viral diarrhea viruses isolated from cattle in Hokkaido, Japan. J Vet Med Sci. 2016;78(1):6170.

10. Neill JD, Workman AM, Hesse R, Bai J, Porter EP, Meadors B, Anderson J, Bayles DO, Falkenberg SM. Identification of BVDV2b and 2c subgenotypes in the United States: genetic and antigenic characterization. Virology. 2019;528: 19-29.

11. Otonel RA, Alfieri AF, Dezen S, Lunardi M, Headley SA, Alfieri AA. The diversity of BVDV subgenotypes in a vaccinated dairy cattle herd in Brazil. Trop Anim Health Prod. 2014;46(1):87-92.

12. Ridpath JF, Bolin SR, Dubovi EJ. Segregation of bovine viral diarrhea virus into genotypes. Virology. 1994;205(1):66-74

13. Vilcek S, Herring AJ, Herring JA, Nettleton PF, Lowings JP, Paton DJ. Pestiviruses isolated from pigs, cattle and sheep can be allocated into at least three genogroups using polymerase chain reaction and restriction endonuclease analysis. Arch Virol. 1994:136(3-4):309-23.

14. Yesilbag K, Alpay G, Becher P. Variability and global distribution of subgenotypes of bovine viral diarrhea virus. Viruses. 2017:9(6):128

15. Yilmaz H, Altan E, Ridpath J, Turan N. Genetic diversity and frequency of bovine viral diarrhea virus (BVDV) detected in cattle in Turkey. Comp Immunol Microbiol Infect Dis. 2012;35(5):411-6.

16. Jenckel M, Hoper D, Schirrmeier H, Reimann I, Goller KV, Hoffmann B, Beer M. Mixed triple: allied viruses in unique recent isolates of highly virulent type 2 bovine viral diarrhea virus detected by deep sequencing. J Virol. 2014:88(12):6983-92.

17. Deng M, Ji S, Fei W, Raza S, He C, Chen Y, Chen H, Guo A. Prevalence study and genetic typing of bovine viral diarrhea virus (BVDV) in four bovine species in China. PLoS One. 2015;10(4):e0121718.
18. Xue F, Zhu YM, Li J, Zhu LC, Ren XG, Feng JK, Shi HF, Gao YR. Genotyping of bovine viral diarrhea viruses from cattle in China between 2005 and 2008. Vet Microbiol. 2010;143(2-4):379-83.

19. Ran X, Chen X, Ma L, Wen X, Zhai J, Wang M, Tong X, Hou G, Ni H. A systematic review and meta-analysis of the epidemiology of bovine viral diarrhea virus (BVDV) infection in dairy cattle in China. Acta Trop. 2019;190: 296-303.

20. Deng M, Chen N, Guidarini C, Xu Z, Zhang J, Cai L, Yuan S, Sun Y, Metcalfe L. Prevalence and genetic diversity of bovine viral diarrhea virus in dairy herds of China. Vet Microbiol. 2020;242:108565.

21. Gong X, Cao X, Zheng F, Chen Q, Zhou J, Yin H, Liu L, Cai X. Identification and characterization of a novel subgenotype of bovine viral diarrhea virus isolated from dairy cattle in northwestern China. Virus Genes. 2013;46(2): 375-6.

22. Zhong F, Li N, Huang X, Guo Y, Chen H, Wang X, Shi C, Zhang X. Genetic typing and epidemiologic observation of bovine viral diarrhea virus in Western China. Virus Genes. 2011:42(2):204-7.

23. Monteiro FL, Cargnelutti JF, Martins B, Noll JG, Weiblen R, Flores EF. Detection of bovine pestiviruses in sera of beef calves by a RT-PCR based on a newly designed set of pan-bovine pestivirus primers. J Vet Diagn Investig. 2019;31(2):255-8.

24. Luzzago C, Ebranati E, Sassera D, Lo Presti A, Lauzi S, Gabanelli E, Ciccozzi M, Zehender G. Spatialand temporal reconstruction of bovine viral diarrhea virus genotype 1 dispersion in Italy. Infect Genet Evol. 2012;122:324-31.

25. Bachofen C, Stalder H, Braun U, Hilbe M, Ehrensperger F, Peterhans E. Coexistence of genetically and antigenically diverse bovine viral diarrhoea viruses in an endemic situation. Vet Microbiol. 2008;131:93-102.

26. Ridpath JF, Fulton RW, Kirkland PD, Neill JD. Prevalence and antigenic diffrences observed between bovine viral diarrhea virus subgenotypes isolated from cattle in Australia and feedlots in the southwestern United States. J Vet Diagn Investig. 2010;22:184-91.

27. Wang W, Shi X, Tong Q, Wu Y, Xia MQ, Ji Y, Xue W, Wu H. A bovine viral diarrhea virus type 1a strain in China: isolation, identification, and experimental infection in calves. Virol J. 2014;11:8.

28. Kalaycioglu AT. Bovine viral diarrhoea virus (BVDV) diversity and vaccination. A review. Vet Q. 2007;29(2):60-7.

29. Hou P, Zhao G, Wang H, He H. Prevalence of bovine viral diarrhea virus in dairy cattle herds in eastern China. Trop Anim Health Prod. 2019;51(4):7918.

30. Ridpath J. Preventive strategy for BVDV infection in North America. Jpn J Vet Res. 2012:60(Suppl):S41-9.

\section{Publisher's Note}

Springer Nature remains neutral with regard to jurisdictional claims in published maps and institutional affiliations.

Ready to submit your research? Choose BMC and benefit from:

- fast, convenient online submission

- thorough peer review by experienced researchers in your field

- rapid publication on acceptance

- support for research data, including large and complex data types

- gold Open Access which fosters wider collaboration and increased citations

- maximum visibility for your research: over $100 \mathrm{M}$ website views per year

At BMC, research is always in progress.

Learn more biomedcentral.com/submission 